\title{
Penanggulangan depresi lansia pascaerupsi Gunung Merapi melalui permainan humor berbasis kearifan budaya lokal pada kader yandu lansia
}

\author{
Sumarni, ${ }^{1, *}$ Triwirasto, ${ }^{1}$ Andrian Fajar Kusumadewi, ${ }^{1}$ Santi Yuliani, ${ }^{2}$ Dwi Nanda Kusumaningrum ${ }^{1}$ \\ ${ }^{1}$ Departemen Ilmu Kedokteran Jiwa, Fakultas Kedokteran, Kesehatan Masyarakat, dan Keperawatan, \\ Universitas Gadjah Mada, Yogyakarta, Indonesia \\ ${ }^{2}$ Rumah Sakit Jiwa Prof. Dr. Soerojo, Magelang, Indonesia
}

\section{Submitted: 24 November 2018 Revised: 10 Januari 2019 Accepted: 12 Januari 2019}

\begin{abstract}
ABSTRAK Kesehatan mental lanjut usia (lansia) pascaerupsi merupakan prioritas utama yang harus diperhatikan untuk mendorong lansia memperoleh rasa sejahtera di usia senja. Erupsi Gunung Merapi merupakan bencana alam yang memberikan efek traumatis jangka panjang pada lansia yang selamat. Berdasarkan besarnya permasalahan kesehatan mental pascaerupsi Gunung Merapi pada lansia, perlu dilakukan pendampingan yang berkelanjutan terkait depresi dan kualitas hidup dengan memberikan pelatihan permainan humor berbasis kearifan budaya lokal dan penanggulangan depresi lansia secara sosial spiritual pada kader pelayanan kesehatan terpadu (yandu) lansia. Keterlambatan penanganan depresi meningkatkan risiko bunuh diri. Tujuan dari penelitian ini yaitu untuk mengevaluasi peningkatan pengetahuan dan keterampilan kader yandu lansia dalam penanggulangan depresi melalui permainan humor berbasis kearifan budaya lokal dan mengevaluasi derajat depresi lansia di Hunian Tetap (Huntap) Kuwang, Cangkringan, Sleman, Daerah Istimewa Yogyakarta (DIY) sebelum dan setelah pelatihan pada kader yandu lansia. Penelitian ini menggunakan data sekunder dari pengabdian masyarakat yang dilaksanakan Mei - September tahun 2014. Sasarannya adalah 30 kader yandu lansia dan 45 lansia di Huntap Kuwang. Alat dan instrumen penelitian yang digunakan yaitu modul permainan humor berbasis kearifan budaya lokal dan peralatannya, modul deteksi dini dan penanggulangan depresi, instrumen Geriatric Depression Scale (GDS), kuesioner pengetahuan dan keterampilan permainan humor berbasis kearifan budaya lokal, serta kuesioner pengetahuan dan keterampilan deteksi dini dan penanggulangan depresi dengan dukungan sosial. Data disajikan secara deskriptif kuantitatif dan kualitatif. Terdapat peningkatan nilai ratarata pada tingkat pengetahuan tentang permainan humor kearifan budaya lokal (dari 66,4 menjadi 93,2), keterampilan (dari 64,1 menjadi 87,6), pengetahuan tentang deteksi dini depresi (dari 47,6 menjadi 84,4), dan keterampilan pemberian dukungan sosial (dari 35,3 menjadi 80,8). Terdapat penurunan kecenderungan depresi pada lansia, dari 36 orang sebelum pelatihan menjadi 17 orang setelah pelaksanaan pelatihan permainan humor berbasis kearifan budaya lokal dan dukungan sosial spiritual. Pelatihan permainan humor kearifan budaya lokal dan deteksi dini kecenderungan depresi serta penanggulangannya pada kader yandu lansia dapat menurunkan kecenderungan depresi dan meningkatkan kualitas hidup lansia di Huntap Kuwang, Cangkringan, Sleman, DIY.
\end{abstract}

KATA KUNCI budaya; depresi; dukungan sosial; lansia; permainan humor

ABSTRACT Mental health of elderly is a main priority which should be concerned of, in order to provide welfare in old age. Merapi eruption was a natural disaster that provided long-term psychological effects on elderly survivors. It is necessary to be handled with continuous support related to depression and life quality

\footnotetext{
*Corresponding author: Sumarni

Departemen IImu Kedokteran Jiwa, Fakultas Kedokteran, Kesehatan Masyarakat, dan Keperawatan, Universitas Gadjah Mada, Jl. Farmako, Sekip Utara, Yogyakarta 55281, Indonesia

E-mail: bu_sumarnidw@yahoo.com
} 
of elderly after Merapi eruption by providing training on humor games based on local cultural wisdom and management of depression in elderly in the manner of social spiritual to the cadres of integrated services for elderly in Hunian Tetap (Huntap) Kuwang, Cangkringa, Sleman, Daerah Istimewa Yogyakarta (DIY). Data used in this research was secondary data taken from community service that conducted in May - September 2014. The community service involved 30 cadres of integrated services for elderly and 45 elderly in Huntap Kuwang. Tools used in this research were module of local wisdom games completed with its equipment and module of early detection and coping with depression. The data were presented in descriptive quantitative and qualitative. After being given training on humor games based on local wisdom, there were increased average score on cadres' knowledge of humor games based on local wisdom (from 66.4 to 93.2) and skill (from 64.1 to 87.6,) as well as knowledge of early detection of depression (from 47.6 to 84.4) and skill of social support providing (from 35.3 to 80.8). There were declining trend of depression in elderly from 36 people before training to 17 people after the training of humor games based on local wisdom and spiritual social support. Training on humor games based on local wisdom and early detection of depressive tendencies along with the coping to the cadres of integrated services can reduce depressive tendencies and improve life quality of elderly in Huntap Kuwang, Cangkringan, Sleman, DIY.

KEYWORDS culture; depression; social support; elderly; humor games

\section{Pendahuluan}

Kesehatan mental orang lanjut usia (lansia) merupakan prioritas utama yang harus diperhatikan untuk memberikan kekuatan dalam memperoleh rasa sejahtera di usia senja. Pada lansia, penyakit sindrom metabolik prevalensinya meningkat. ${ }^{1,2}$ Berbagai macam penyakit degeneratif dan penyakitpenyakit fisik kronis akan meningkatkan gangguan jiwa. ${ }^{3}$ Gangguan sindrom metabolik akan memicu terjadinya depresi. ${ }^{4-7}$

Erupsi Gunung Merapi merupakan bencana alam hebat yang traumatik dan menyebabkan trauma psikologis bagi lansia dan memperberat depresinya. ${ }^{8,9}$ Bencana alam memberikan efek psikologis jangka panjang. Pada sekitar 40,0\% - 68,0\% korban bencana alam, efek tersebut dapat bertahan selama 10 tahun ke depan dalam kehidupan mereka. ${ }^{10}$ Penelitian Jia dan kawankawan. ${ }^{11}$ menunjukkan bahwa kelompok lansia yang selamat dari bencana lebih rentan mengalami post-traumatic stress disorder dan gangguan kejiwaan.

Di samping mengalami peristiwa yang sangat traumatis, lansia di Hunian Tetap (Huntap) Kuwang banyak yang kehilangan keluarga (suami/ istri, anak, menantu, dan cucu) akibat erupsi Gunung Merapi. Stres yang berkepanjangan, kehilangan tempat tinggal, kehilangan harta benda, kehilangan pekerjaan, kehilangan lahan pertanian, tidak mempunyai kegiatan, tidak mempunyai penghasilan, dan kehilangan teman dekat akan memperberat depresinya. Sebagian tetangga mereka berasal dari dusun yang berbeda sehingga para lansia harus beradaptasi dengan teman-teman baru. Lansia merasa kesepian dan tidak ada kegiatan sehingga lebih sering duduk-duduk dan melamun. Selain itu, lansia jarang diikutsertakan oleh kader dalam kegiatan kemasyarakatan seperti organisasi Pemberdayaan dan Kesejahteraan Keluarga (PKK).

Tantangan-tantangan yang dihadapi di daerah bencana adalah bangunan huntap yang tidak ramah lansia, seperti letak rumah yang terlalu tinggi terhadap jalan, tidak ada pegangan, dan lokasinya jauh dengan balai pertemuan. Di samping itu, kurangnya dukungan keluarga dalam kegiatan lansia, seperti mengantar ke pasar, mencari rumput, dan mengantar ke pengajian, serta tidak adanya transportasi yang bisa masuk ke huntap, merupakan tantangan tersendiri.

Menurut hasil penelitian Sumarni, ${ }^{12}$ sekitar 90,4\% lansia yang berada di Hunian Sementara (Huntara) Gondang, Cangkringan, Sleman, Daerah Istimewa Yogyakarta (DIY) mengalami kecenderungan depresi ringan, sedang, dan berat. Hal ini pada gilirannya akan mengakibatkan 
disabilitas yang memungkinkan munculnya kemungkinan untuk mengakhiri hidup. Sudah dilakukan penelitian penanggulangan depresi pascaerupsi pada lansia di Huntara Gondang di mana hasilnya menunjukkan bahwa permainan kearifan budaya lokal dan dukungan spiritual dapat menurunkan kecenderungan depresi pada lansia. ${ }^{12}$

Berdasarkan besarnya permasalahan pada lansia yang berhubungan dengan kesehatan mental pascaerupsi Gunung Merapi, perlu dilakukan pendampingan berkelanjutan terkait dengan depresi dan kualitas hidup pada lansia. Keterlambatan penanganan depresi pada lansia dapat meningkatkan penyakit degeneratif, disabilitas, dan risiko melakukan bunuh diri. Menurut World Health Organization (WHO), depresi diprediksi menjadi penyebab kematian kedua setelah penyakit jantung dan kanker pada tahun 2020. ${ }^{13}$ Di Huntap Kuwang, Cangkringan, Sleman, DIY belum pernah dilakukan penanganan lansia pascaerupsi Gunung Merapi secara berkelanjutan dengan permainan humor berbasis kearifan budaya lokal dan penanggulangan depresi lansia secara sosial spiritual yang dilakukan oleh kader-kader yandu lansia. Kader yandu lansia merupakan garda terdepan yang memiliki posisi yang sangat strategis dalam menangani kesehatan mental lansia pascaerupsi Gunung Merapi.

Tujuan kegiatan ini adalah untuk meningkatkan pengetahuan dan keterampilan kader yandu lansia di Huntap Kuwang, Cangkringan, Sleman, DIY dalam melakukan permainan humor berbasis kearifan budaya local, deteksi dini kecenderungan depresi lansia, serta memberikan pendekatan dukungan sosial spiritual. Selain itu, tujuan kegiatan ini yaitu untuk mengevaluasi perubahan kecenderungan depresi lansia di Huntap Kuwang dengan membandingkan antara sebelum dan sesudah pelatihan pada kader yandu lansia.

\section{Metode}

Data yang digunakan merupakan data sekunder dari kegiatan pengabdian masyarakat yang dilakukan di Huntap Kuwang, Kecamatan Cangkringan, Kabupaten Sleman pada bulan Mei-September
2014. Sasarannya adalah 30 kader yandu lansia dan 45 lansia di Huntap Kuwang. Alat yang digunakan adalah modul permainan humor berbasis kearifan budaya lokal dan peralatannya, serta modul deteksi dini dan penanggulangan depresi. Instrumen yang digunakan adalah Geriatric Deppresion Scale (GDS), kuesioner pengetahuan dan keterampilan permainan humor berbasis kearifan budaya lokal, dan kuesioner pengetahuan dan keterampilan deteksi dini dan penanggulangan depresi dengan dukungan sosial. Data disajikan secara deskriptif kuantitatif dan kualitatif.

Tahap-tahap kegiatan ini adalah memberikan pelatihan permainan humor berbasis kearifan budaya lokal pada kader yandu lansia dan lansia di Huntap Kuwang, Cangkringan dengan modul permainan kearifan budaya lokal sebanyak 4 kali selama satu bulan, memberikan pelatihan deteksi dini kecenderungan depresi dan penanggulangan depresi lansia secara sosial spiritual dengan memberikan dukungan sosial emosional, instrumental, informasional, penghargaan, dan spiritual pada kader yandu lansia dan lansia di Huntap Kuwang, Cangkringan dengan modul penanggulangan depresi lansia sebanyak 4 kali selama 1 bulan, melakukan pendampingan kader yandu lansia dalam mengaplikasikan permainan kearifan budaya lokal dan dukungan sosial pada lansia dalam kegiatan pertemuan yandu lansia dan senam lansia 3 kali selama 1 bulan, dan melakukan pendampingan kader yandu lansia dalam mengaplikasikan permainan kearifan budaya lokal pada lansia dalam acara memperingati hari kemerdekaan Indonesia.

\section{Hasil}

Setelah diberikan pelatihan permainan humor berbasis kearifan budaya lokal pada kader yandu lansia, nilai rata-rata pengetahuan dan keterampilan tentang permainan humor kearifan budaya lokal mengalami peningkatan (Tabel 1 dan 2).

Nilai rata-rata tingkat pengetahuan tentang permainan humor berbasis kearifan budaya lokal kader yandu lansia meningkat dari 66,4 menjadi 93,2 . Sementara itu nilai rata-rata keterampilan 
permainan humor kearifan budaya lokal kader yandu lansia mengalami peningkatan dari 64,1 menjadi 87,9. Kegiatan pelatihan kader dalam peningkatan pengetahuan dan keterampilan terkait permainan humor ditampilkan dalam Gambar 1.

Setelah diberikan pelatihan deteksi dini kecenderungan depresi dan penanggulangannya dengan dukungan sosial, nilai rata-rata pengetahuan dan keterampilan melakukan deteksi dini dan penanggulangan depresi mengalami peningkatan. Nilai rata-rata pengetahuan tentang deteksi dini depresi kader yandu lansia dari 45,1 meningkat menjadi 84,3 (Tabel 3), sedangkan nilai keterampilan deteksi dini dan pemberian dukungan sosial meningkat dari 35,3 menjadi 80,8 (Tabel 4). Kegiatan pelatihan kader dalam peningkatan deteksi dini depresi dalam penanggulangan depresi ditampilkan pada Gambar 2.

Setelah diberikan pelatihan humor berbasis kearifan budaya lokal dan penanggulangan depresi dengan memberikan dukungan sosial pada kader yandu lansia, kecenderungan depresi lansia mengalami penurunan. Terdapat penurunan kecenderungan depresi pada lansia dari 36 orang yang mengalami kecenderungan depresi menjadi 17 orang yang mengalami kecenderungan depresi (Tabel 5).

Tabel 1. Tingkat pengetahuan permainan humor berbasis kearifan budaya lokal pada kader yandu lansia di Huntap Kuwang

\begin{tabular}{lccc}
\hline \multicolumn{1}{c}{$\begin{array}{c}\text { Pengetahuan permainan humor berbasis kearifan budaya } \\
\text { lokal }\end{array}$} & \multicolumn{3}{c}{ Nilai rata-rata pengetahuan } \\
\cline { 2 - 4 } & Sebelum & Sesudah & Perubahan \\
\hline $\begin{array}{l}\text { Pengetahuan macam-macam permainan humor dan lagu-lagu } \\
\text { yang mengiringi }\end{array}$ & 64,5 & 92,2 & $+27,8$ \\
$\begin{array}{l}\text { Pengetahuan macam-macam lagu berbasis kearifan budaya } \\
\text { lokal }\end{array}$ & 68,3 & 94,2 & $+25,8$ \\
\hline Rata - rata & 66,4 & 93,2 & $+26,8$ \\
\hline
\end{tabular}

Tabel 2. Perubahan rata-rata nilai keterampilan permainan humor berbasis kearifan budaya lokal dan keterampilan menyanyikan, menari lagu-lagu berbasis kearifan budaya lokal pada kader yandu lansia di Huntap Kuwang

\begin{tabular}{|c|c|c|c|}
\hline \multirow{2}{*}{$\begin{array}{l}\text { Keterampilan permainan humor berbasis kearifan budaya } \\
\text { lokal dan lagu-lagu }\end{array}$} & \multicolumn{3}{|c|}{ Nilai rata-rata keterampilan } \\
\hline & Sebelum & Sesudah & Perubahan \\
\hline Keterampilan bermain dan lagu-lagu yang mengiringi & 62,8 & 86,1 & $+23,3$ \\
\hline $\begin{array}{l}\text { Keterampilan menyanyi dan menari lagu-lagu berbasis } \\
\text { kearifan budaya lokal }\end{array}$ & 65,4 & 89,6 & $+24,2$ \\
\hline Rata - rata & 64,1 & 87,9 & $+23,8$ \\
\hline
\end{tabular}
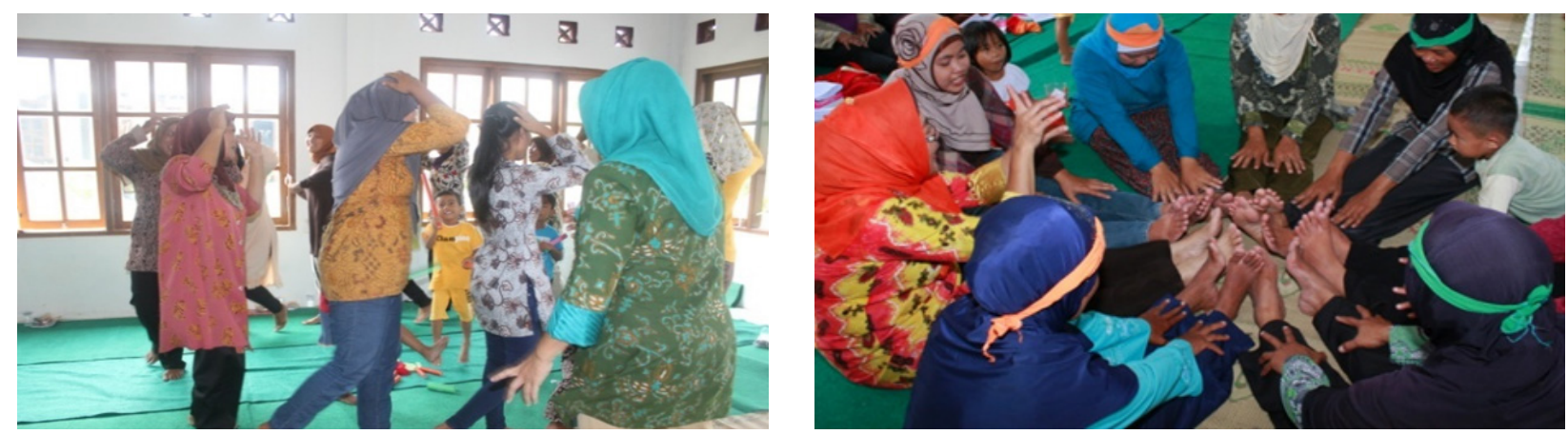

Gambar 1. Kader dilatih mempraktikkan langsung permainan humor berbasis kearifan budaya lokal bersama lansia 
Tabel 3. Tingkat pengetahuan deteksi dini dan penanggulangan secara sosial depresi lansia pada kader yandu lansia di Huntap Kuwang

\begin{tabular}{lccc}
\hline \multirow{2}{*}{$\begin{array}{c}\text { Macam-macam pengetahuan deteksi dini depresi } \\
\text { pada lansia dan penanganan secara sosial }\end{array}$} & \multicolumn{2}{c}{ Nilai rata-rata tingkat pengetahuan } \\
\cline { 2 - 4 } & Sebelum & Sesudah & Perubahan \\
\hline Pengertian dan gejala-gejala depresi pada lansia & 51,7 & 83,3 & $+31,7$ \\
Faktor-faktor yang mempengaruhi depresi & 46,7 & 85,0 & $+38,3$ \\
Pengukuran depresi lansia & 38,5 & 83,1 & $+44,6$ \\
Penanganan secara sosial depresi lansia & 43,8 & 86,2 & $+42,4$ \\
\hline Rata-rata & 45,1 & 84,3 & $+39,2$ \\
\hline
\end{tabular}

Tabel 4. Perubahan tingkat keterampilan deteksi dini dan penanggulangan secara sosial depresi lansia pada kader yandu lansia

\begin{tabular}{lccc}
\hline \multirow{2}{*}{$\begin{array}{l}\text { Macam-macam Keterampilan deteksi dini depresi } \\
\text { lansia dan penanganan secara sosial }\end{array}$} & \multicolumn{2}{c}{ Nilai rata-rata tingkat keterampilan } \\
\cline { 2 - 4 } & Sebelum & Sesudah & Perubahan \\
\hline Keterampilan deteksi dini depresi lansia & 29,3 & 80,6 & $+51,3$ \\
Keterampilan penanganan lansia secara sosial depresi & 41,3 & 81,1 & $+39,8$ \\
lansia & & & \\
\hline Rata-rata & 35,3 & 80,8 & $+45,6$ \\
\hline
\end{tabular}
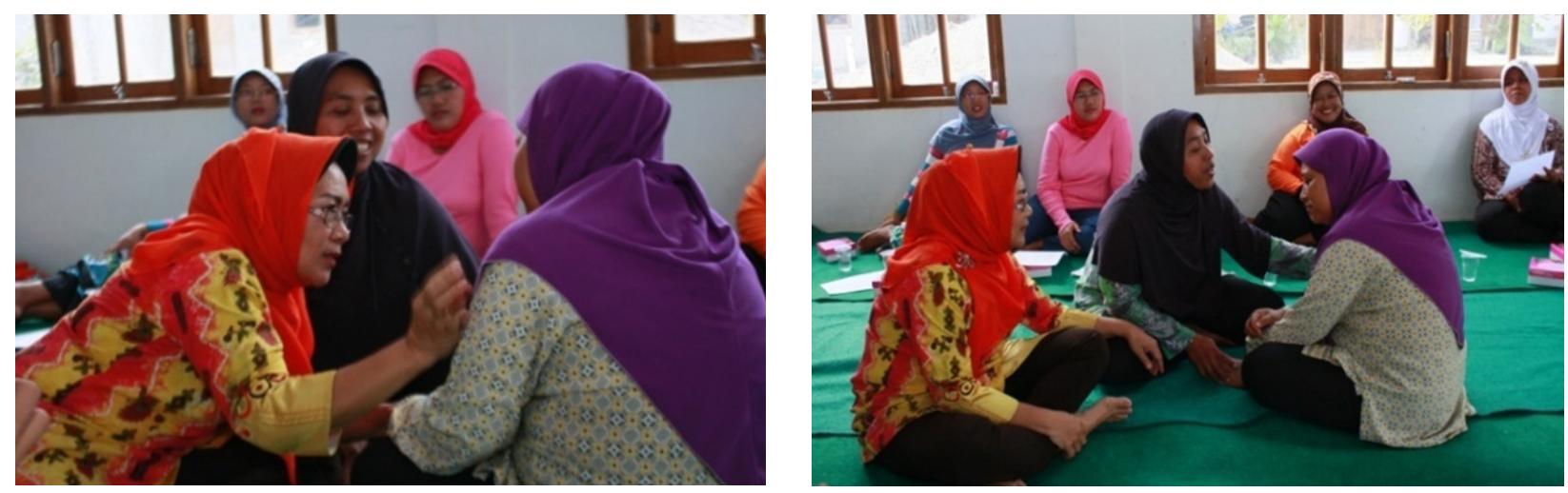

Gambar 2. Kader posyandu lansia dilatih deteksi dini depresi dalam penanggulangan depresi dengan memberikan dukungan sosial pada lansia

Tabel 5. Perubahan kecenderungan depresi pada lansia di Huntap Kuwang

\begin{tabular}{lccc}
\hline \multirow{2}{*}{ Kecenderungan depresi } & \multicolumn{3}{c}{ Banyaknya lansia } \\
\cline { 2 - 4 } & Sebelum pelatihan & Sesudah pelatihan & Perubahan \\
\hline Normal & 9 & 28 & +19 \\
Kecenderungan depresi & 36 & 17 & -19 \\
\hline
\end{tabular}

\section{Pembahasan}

Dalam kegiatan permainan humor berbasis kearifan budaya lokal, bersamaaan dengan mendengarkan musik, menyanyi, dan menari bersama akan memberikan keuntungan secara fisik, seperti peningkatan koordinasi dan kekuatan otot. Secara emosional, kegiatan tersebut membantu mengeksplorasikan emosi seperti rasa kehilangan yang sulit diungkapkan secara verbal, kemarahan, frustasi, dan membantu lansia merasa lebih gembira. Secara sosial, kegiatan tersebut dapat 
mengurangi perasaan terisolasi dan meningkatkan keterampilan bersosialisasi. Secara mental, kegiatan tersebut membantu peningkatan keterampilan kognitif, ingatan, motivasi, mengurangi stres, dan kecemasan. Permainan dan lagu tradisional berbasis kearifan budaya lokal dan spiritual yang mempunyai nilai-nilai luhur dan filosofi Jawa yang sangat kuat, akan meningkatkan semangat, mengurangi stres, menimbulkan perasaan senang, dan meningkatkan imunitas. ${ }^{12,14}$

Peningkatan keterampilan permainan humor berbasis kearifan budaya lokal pada kader yandu lansia dan lansia dapat meningkatkan rasa senang atau gembira, serta dapat melepaskan stres dari rutinitas kegiatan sehari-hari sebagai ibu rumah tangga, baik bagi kader yandu lansia maupun para lansia. Secara teoritis, kegembiraan disertai tertawa lepas dapat mempengaruhi kadar neurotransmiter dan hormon-hormon di otak. Neurotransmiter tersebut adalah dopamin dan serotonin serta hormon oksitosin dan endorfin. Dopamin berhubungan dengan kadar kepuasan dan kadarnya akan meningkat bila seseorang sebagai individu merasa penting bagi orang lain. Oksitosin kadarnya meningkat bila orang saling mempercayai satu sama lain. Endorfin kadarnya meningkat bila seseorang merasa bahagia dan rileks. ${ }^{15}$

Kader yandu lansia bersama dengan lansia bermain secara berkelompok sehingga mereka mendapatkan kepuasan karena kebutuhan diajak dalam kegiatan, dihargai, disayang, dipuji, dan dipeluk terpenuhi. Harga diri pada lansia meningkat karena sebagian besar permainan
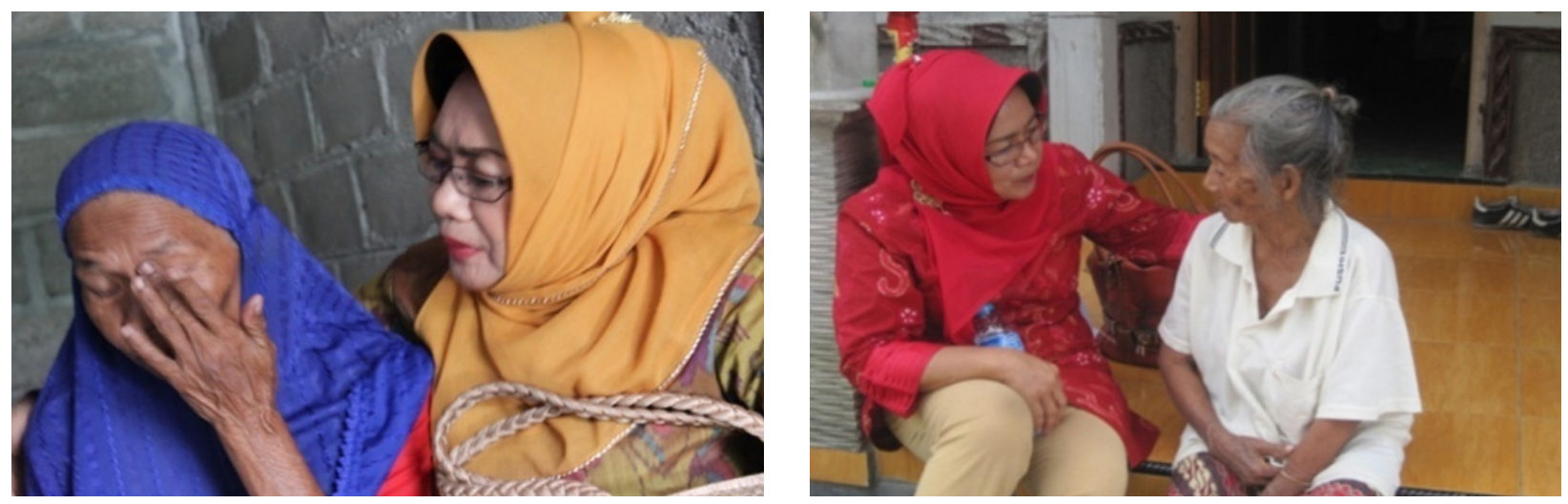

Gambar 3. Ekspresi lansia-lansia yang sedih dan murung sebelum dilaksanakan pelatihan permainan humor berbasis kearifan budaya lokal dan dukungan sosial spiritual
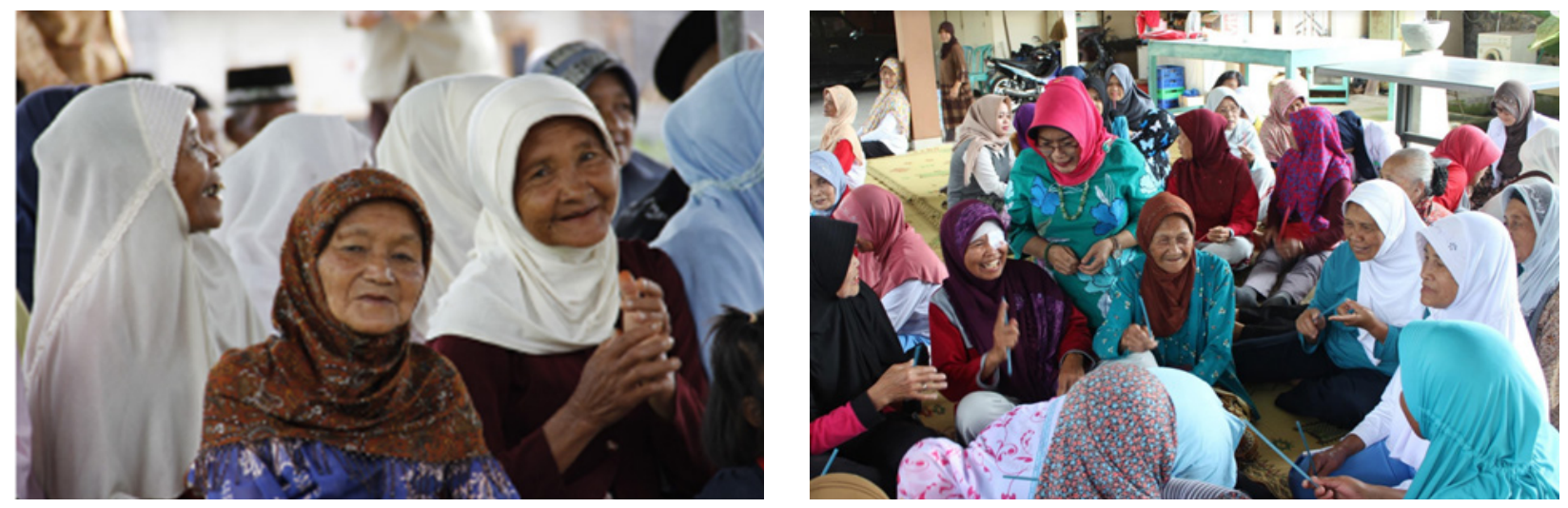

Gambar 4. Ekspresi lansia setelah pelatihan permainan humor berbasis kearifan budaya lokal 
yang diajarkan membutuhkan kerja sama yang baik antarlansia. Dengan demikian lansia akan merasa bahwa dirinya penting dan mampu. Adanya kerja sama ini juga menumbuhkan rasa saling percaya di antara lansia. Permainan yang menyenangkan juga menciptakan suasana yang santai dan rileks sehingga akan berpengaruh pada kondisi kejiwaan lansia. Semua ini terkait dengan harmonisasi keempat neurotransmiter tersebut di atas.

Permainan yang menyenangkan menyebabkan perubahan fisiologis pada beberapa sistem dalam tubuh. Sistem tersebut antara lain sistem muskuloskeletal, sistem kardiovaskuler, sistem endokrin, sistem imunologis, serta sistem saraf. ${ }^{16}$ Selain itu juga menyebabkan perubahan pada sistem kerja katekolamin dan kadar kortisol sehingga berpengaruh terhadap sistem imun. ${ }^{17,18}$ Tertawa terbahak-bahak pada lansia dan kader yandu lansia dapat mengurangi ketegangan otot, menurunkan tekanan darah, meningkatkan oksigenasi jaringan, melatih kekuatan jantung, dan menarik produksi endorfin. Tertawa secara berkelompok lebih efektif dibanding tertawa secara individual dalam meningkatkan kesehatan. Penelitian Dezeache (2012) menyebutkan bahwa tertawa bersamasama dapat meningkatkan lonjakan endorfin yang dapat ditularkan pada teman-teman yang lain. ${ }^{19} \mathrm{Hal}$ ini sangat bermanfaat dalam interaksi sosial dan meningkatkan kepuasan diri.

Pada setiap awal dan akhir permainan selalu diisi dengan doa dan pengambilan nafas dalamdalam sebagai pemanasan dan pendinginan untuk meningkatkan relaksasi sehingga menurunkan depresi. ${ }^{11}$ Pemberian sentuhan dan pujian setiap selesai permainan akan meningkatkan rasa percaya diri, dihargai, senang, dan semangat sehingga akan meningkatkan endorfin dan menurunkan depresi. ${ }^{20}$ Dalam kegiatan pemberian dukungan sosial emosional, penghargaan, instrumental, informasi, dan spiritual, lansia mendapatkan kenikmatan berupa perasaan puas, tenang, nyaman, dan damai yang akan meningkatkan dopamin. ${ }^{21}$ Lansia yang mendapatkan perasaan dihargai, dicintai, dan ditenangkan akan memicu meningkatnya hormon dopamin. ${ }^{22}$ Mendapatkan kenikmatan berupa perasaan dipercayai kemampuannya dalam melakukan permainan mampu meningkatkan hormon oksitosin. ${ }^{23}$ Dukungan sosial meningkatkan perasaan senang, dimana akan menurunkan kadar hormon kortisol. ${ }^{24}$ Pada gilirannya semua peningkatan hormon dan penurunan kadar kortisol akan berdampak terhadap penurunan depresi. Dukungan sosial dapat mempengaruhi kesehatan mental, fisik, kognisi, dan perilaku.

Penanggulangan depresi lansia dengan permainan humor berbasis kearifan budaya lokal mampu mengurangi kecenderungan depresi yang terjadi pascaerupsi Gunung Merapi. Kelemahan penelitian ini adalah penggunaan data sekunder dari tahun 2014 sehingga kemungkinan ada data yang tidak valid dan tidak dapat dianalisis lebih jauh secara statistik.

\section{Kesimpulan}

Pelatihan permainan humor berbasis kearifan budaya lokal bagi kader yandu lansia dapat meningkatkan pengetahuan dan keterampilan kader yandu lansia dalam memberikan permainan humor berbasis kearifan budaya lokal kepada lansia. Pelatihan deteksi dini dan penanganan depresi lansia secara sosial bagi kader yandu lansia dapat meningkatkan pengetahuan dan keterampilan kader yandu lansia dalam melakukan deteksi dini dan penanganan depresi secara sosial pada lansia. Pemberian permainan humor berbasis kearifan budaya lokal dan penanganan depresi lansia secara sosial dapat menurunkan kecenderungan depresi lansia di Huntap Kuwang, Cangkringan, Sleman, DIY.

Dinas kesehatan diharapkan agar lebih memperhatikankesehatanmentallansiapascaerupsi Gunung Merapi dengan memberdayakan kader yandu lansia untuk memberikan permainanan humor berbasis kearifan budaya lokal dan penanggulangan depresi. Puskesmas Cangkringan dapat menerapkan permainan kearifan budaya lokal dan dukungan sosial dalam kegiatan rutin senam lansia di puskesmas. 


\section{Ucapan terima kasih}

Terima kasih kami ucapkan kepada Prof. Dr. Suratman, M.Sc, selaku Ketua Lembaga Penelitian dan Pengabdian kepada Masyarakat (LPPM), Universitas Gadjah Mada (UGM), Dr. Puji Astuti, S.Si., M.Sc., Apt, selaku Ketua Bidang Pengabdian Masyarakat Berbasis Penerapan Teknologi Tepat Guna LPPM UGM, dan segenap jajaran LPPM UGM yang telah memberikan kepercayaan, dana, dan fasilitas untuk pelaksanaan kegiatan pengabdian masyarakat ini. Selain itu, ucapan terima kasih juga kami sampaikan kepada ibu-ibu kader yandu lansia dan para lansia di Huntap Kuwang, serta Bapak dan Ibu Dukuh Huntap Kuwang yang telah dengan tekun mengikuti pelatihan dalam kegiatan pengabdian masyarakat ini sampai selesai.

\section{Konflik kepentingan}

Penulis menyatakan tidak ada konflik kepentingan dalam penelitian ini.

\section{Daftar pustaka}

1. Arai $H$, Yamamoto $A$, Matsuzawa $Y$, Saito $Y$, Yamada N, Oikawa $S$, et al. Prevalence of the metabolic syndrome in elderly and middleaged Japanese. J Clin Gerontol Geriatr. 2010;1(2):42-7.

2. Sinclair A, Viljoen A. The metabolic syndrome in older persons. Clin Geriatr Med. 2010;26(2):261-74.

3. Maslim R. Prevalensi dan distribusi masalah kesehatan jiwa di Indonesia: Suatu kajian epidemiologi psikiatri. Universitas Gadjah Mada; 2012.

4. Akbaraly TN, Ancelin M-L, Jaussent I, Ritchie C, Barberger-Gateau P, Dufouil C, et al. Metabolic syndrome and onset of depressive symptoms in the elderly: Findings from the three-city study. Diabetes Care. 2011;34(4):904-9.

5. Sekita A, Arima $H$, Ninomiya $T$, Ohara $T$, Doi $\mathrm{Y}$, Hirakawa $\mathrm{Y}$, et al. Elevated depressive symptoms in metabolic syndrome in a general population of Japanese men: A cross-sectional study. BMC Public Health. 2013;13:862.

6. Vanhala $M$, Jokelainen J, KeinänenKiukaanniemi S, Kumpusalo E, Koponen $\mathrm{H}$. Depressive symptoms predispose females to metabolic syndrome: A 7-year follow-up study. Acta Psychiatr Scand. 2009;119(2):137-42.

7. Viinamäki $\mathrm{H}$, Heiskanen $\mathrm{T}$, Lehto $\mathrm{SM}$, Niskanen $\mathrm{L}$, Koivumaa-Honkanen $\mathrm{H}$, Tolmunen $\mathrm{T}$, et al. Association of depressive symptoms and metabolic syndrome in men. Acta Psychiatr Scand. 2009;120(1):23-9.

8. Nurhasanah, Kushadiwijaya $H$, Marchira $C$. Hubungan tingkat depresi dengan kualitas hidup pada masyarakat daerah bencana pasca gempa bumi di Kabupaten Sleman tahun 2008. Berita Kedokteran Masyarakat. 2012;25(1):1.

9. Kaplan HL, Friedman AM, Sadock BJ. Comprehensive textbook of psychiatry. Baltimore: William Wilkins; 1995.

10. Fullerton CS, Ursano RJ. Psycological and psychopathological consequences of disaster. In: Lopez-Ibor JJ, Christodouou G, Maj M, Satorius $\mathrm{N}$, Okhasa $\mathrm{A}$, editor. Disaster and Mental Health. England: John Wiley \& sons Ltd; 2005. p. 13-36.

11. Jia Z, Tian W, Liu W, Cao Y, Yan J, Shun Z. Are the elderly more vulnerable to psychological impact of natural disaster? A populationbased survey of adult survivors of the 2008 Sichuan earthquake. BMC Public Health. 2010;10(1):172.

12. Sumarni DW. Laporan Penelitian Damas Fakultas Kedokteran: Pengaruh permainan kearifan lokal terhadap depresi, kualitas tidur, gangguan kognitif, gangguan interaksi sosial pada lansia di Huntap Gondang Cangkringan Sleman. Yogyakarta: Universitas Gadjah Mada; 2012.

13. World Health Organization. The world health report 2001 mental health: New understanding, new hope [Internet]. Geneva; 2001. [cited 2018 October 23]. Available from: http://www.who.int/iris/handle/10665/42390

14. Hartoto. Pendidikan rekreasi. Yogyakarta: FPOK IKIP; 1995. 
15. StahISM.Stahl'sessential psychopharmacology: Neuroscientific basis and practical applications. 3rd ed. New York: Cambridge University Press; 2008.

16. Fry WF. The biology of humor. Int J Humor Res. 1994;7(2):111-26.

17. Hubert $W$, de Jong-Meyer R. Autonomic, neuroendocrine, and subjective responses to emotion-inducing film stimuli. Int J Psychophysiol. 1991;11(2):131-40.

18. McDaniel ND. Touching makes you healthier [Internet]. Health Magazine; 2011 [cited 2014 March 5]. Available from: http://edition.ccn. com/2011/HEALTH/0105/touching.makes. you.healthier.health/index.htm

19. Dezecache G, Dunbar RIM. Sharing the joke: The size of natural laughter groups. Evol Hum Behav. 2012;33(6):775-9.
20. Carlson NR. Physiology of behavior. 8th ed. Boston: Pearson Education, Inc; 2004.

21. Camara E, Rodriguez-Fornells A, Ye Z, Münte TF. Reward networks in the brain as captured by connectivity measures. Front Neurosci. 2009;3(3):350-62.

22. Rasheed N, Alghasham A. Central dopaminergic system and its implications in stress-mediated neurological disorders and gastric ulcers: Short review. Adv Pharmacol Sci. 2012;2012:1-11.

23. Miyazaki T, Takase K, Nakajima W, Tada H, Ohya D, Sano A, et al. Disrupted cortical function underlies behavior dysfunction due to social isolation. J Clin Invest. 2012;122(7):2690-701.

24. McEwen BS. Physiology and neurobiology of stress and adaptation: Central role of the brain. Physiol Rev. 2007;87(3):873-904. 